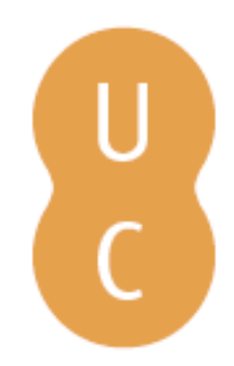

\title{
nombalina
}

\section{Gabriel da Fonseca: a New Christian doctor in Bernini's Rome}

Autor(es): $\quad$ Nelson Novoa, James W.

Publicado por: UA Editora - Universidade de Aveiro; Imprensa da Universidade de

URL

persistente: URI:http://hdl.handle.net/10316.2/35695

DOI: $\quad$ DOI:http://dx.doi.org/10.14195/978-989-26-0941-6_9

Accessed : $\quad$ 26-Apr-2023 14:46:20

A navegação consulta e descarregamento dos títulos inseridos nas Bibliotecas Digitais UC Digitalis, UC Pombalina e UC Impactum, pressupõem a aceitação plena e sem reservas dos Termos e Condições de Uso destas Bibliotecas Digitais, disponíveis em https://digitalis.uc.pt/pt-pt/termos.

Conforme exposto nos referidos Termos e Condições de Uso, o descarregamento de títulos de acesso restrito requer uma licença válida de autorização devendo o utilizador aceder ao(s) documento(s) a partir de um endereço de IP da instituição detentora da supramencionada licença.

Ao utilizador é apenas permitido o descarregamento para uso pessoal, pelo que o emprego do(s) título(s) descarregado(s) para outro fim, designadamente comercial, carece de autorização do respetivo autor ou editor da obra.

Na medida em que todas as obras da UC Digitalis se encontram protegidas pelo Código do Direito de Autor e Direitos Conexos e demais legislação aplicável, toda a cópia, parcial ou total, deste documento, nos casos em que é legalmente admitida, deverá conter ou fazer-se acompanhar por este aviso.

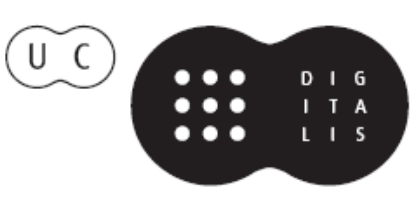




\section{HUMANISMO E CIÊNCIA Antiguidade e Renascimento}

António Manuel Lopes Andrade

Carlos de Miguel Mora

João Manuel Nunes Torrão
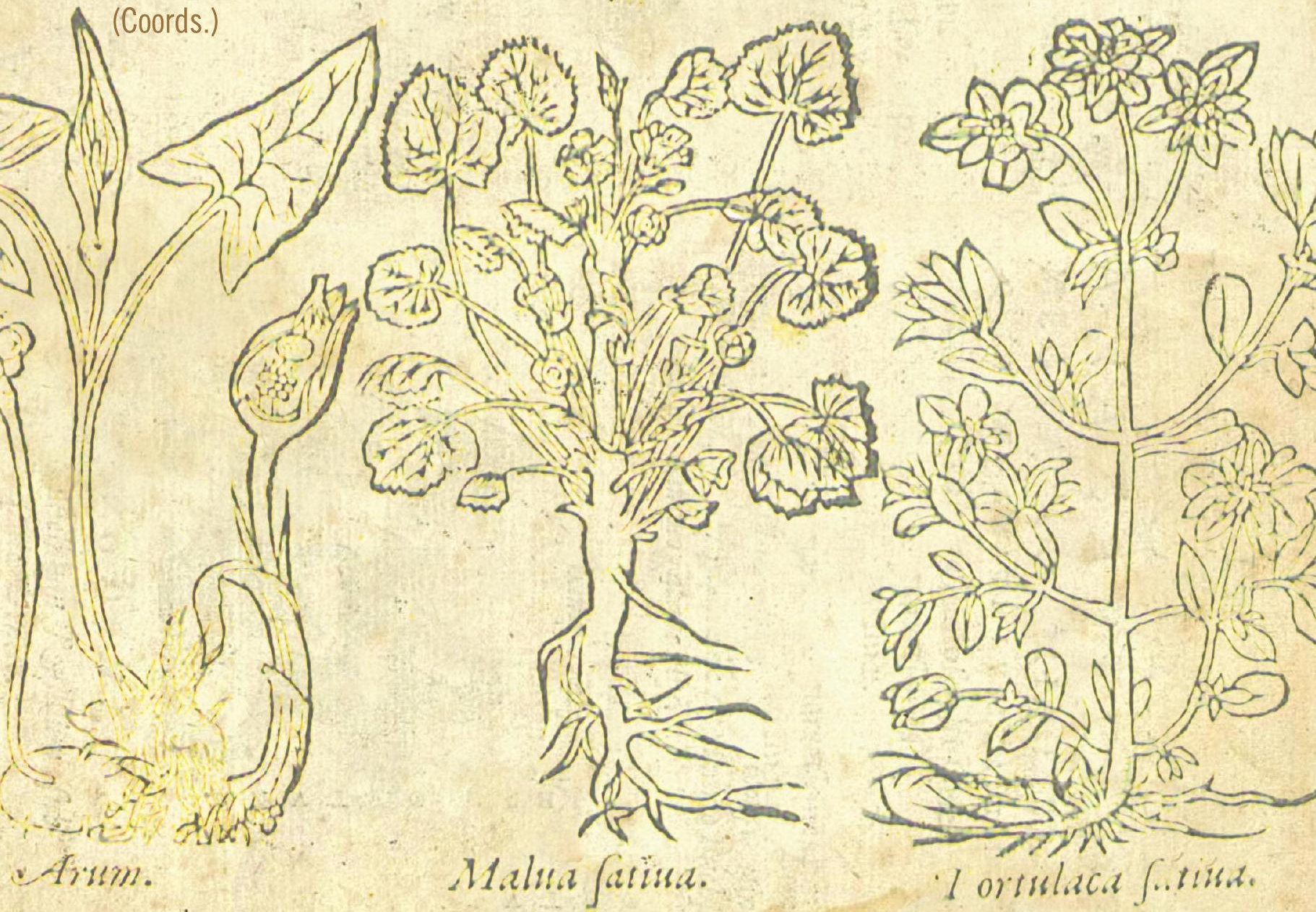

Aveiro I Coimbra I São Paulo 2015

UA Editora - Universidade de Aveiro I Imprensa da Universidade de Coimbra I Annablume 
Este volume resulta de várias iniciativas desenvolvidas no âmbito do projecto de I\&D "Dioscórides e o Humanismo Português: os Comentários de Amato Lusitano" (http://amatolusitano.web.ua.pt), recoIhendo contribuições de mais de duas dezenas de colaboradores, tanto de membros da equipa como de outros investigadores nacionais e estrangeiros. Entre os eventos que estiveram na origem deste livro destacam-se as três edições do Ciclo de Conferências promovido pelo projecto, realizadas entre 2010 e 2013, e sobretudo o Colóquio Internacional "Dioscórides e o Humanismo Português: os Comentários de Amato Lusitano", que decorreu no Departamento de Línguas e Culturas da Universidade de Aveiro, nos dias 21 e 22 de Novembro de 2013.

0 objectivo principal do projecto é a edição e tradução para português dos dois livros que Amato Lusitano dedicou ao comentário do tratado grego De materia medica de Dioscórides, ou seja, o Index Dioscoridis (Antuérpia, 1536) e as In Dioscoridlis Anazarbei de medica materia libros quinque... enarrationes (Veneza, 1553), estando contemplada, também, a tradução de mais duas obras directamente correlacionadas com os livros do médico português: a montante, a do próprio tratado grego de Dioscórides; a jusante, a do livro intitulado Apologia adversus Amathum Lusitanum (Veneza, 1558) de Pietro Andrea Mattioli.

OBRA PUBLICADA COM A COORDENAÇÃO

CIENTÍFICA DE:

Centro de Línguas, Literaturas e Culturas da Universidade de Aveiro

Centro de Estudos Clássicos e Humanísticos da Universidade de Coimbra

Cátedra de Estudos Sefarditas "Alberto

Benveniste" da Faculdade de Letras da Universidade de Lisboa 


\section{HUMANISMO E CIÊNCIA}

\section{Antiguidade e Renascimento}

ANTÓNIO MANUEL LOPES ANDRADE

CARLOS DE MIGUEL MORA

JOÃO MANUEL NUNES TORRÃO

(COORDS.)

AVEIRO • COIMBRA • SÃO PAULO

2015

UA EDITORA • UNIVERSIDADE DE AVEIRO

IMPRENSA DA UNIVERSIDADE DE COIMBRA

ANNABLUME 


\section{HUMANISMO E CIÊNCIA: Antiguidade e Renascimento}

\author{
EDIÇÃO

UA EDITORA • UNIVERSIDADE DE AVEIRO
IMPRENSA DA UNIVERSIDADE DE COIMBRA
ANNABLUME

ORGANIZAÇÃO E COORDENAÇÃO EDITORIAL ANTÓNIO MANUEL LOPES ANDRADE

CARLOS DE MIGUEL MORA

JOÃO MANUEL NUNES TORRÃO

\author{
DESIGN DA CAPA \\ MEIOKILO DESIGN STUDIO
}

DESIGN

CARLOS COSTA

IMPRESSÃO E ACABAMENTO

SERSILITO • MAIA

ISBN

UA • 978-972-789-434-5

IUC • 978-989-26-0940-9

\section{ISBN DIGITAL}

UA • 978-972-789-435-2

IUC • 978-989-26-0941-6

DOI

http://dx.doi.org/10.14195/ 978-989-26-0941-6

DEPÓSITO LEGAL 368241/13

TIRAGEM 500 Exemplares

(C) 2015

UA EDITORA • UNIVERSIDADE DE AVEIRO IMPRENSA DA UNIVERSIDADE DE COIMBRA

ANNABLUME

\section{COMISSÃO CIENTÍFICA}

António Manuel Lopes Andrade

Carlos de Miguel Mora

Delfim Ferreira Leão

Henrique Leitão

João Manuel Nunes Torrão

Maria de Fátima Reis

Maria do Céu Zambujo Fialho

Miguel Ángel González Manjarrés

\section{TEXTOS}

Adelino Cardoso

Ana Leonor Pereira

Ana Margarida Borges

António Guimarães Pinto

António Maria Martins Melo

Bernardo Mota

Carlos A. Martins de Jesus

Carlos de Miguel Mora

Cristina Santos Pinheiro

Donald Beecher

Emília Oliveira

Isabel Malaquias

James W. Nelson Novoa

Joana Mestre Costa

João Manuel Nunes Torrão

João Rui Pita

Jorge Paiva

José Sílvio Moreira Fernandes

Maria de Fátima Silva

Miguel Ángel González Manjarrés

Rui Manuel Loureiro

Telmo Corujo dos Reis

Teresa Nobre de Carvalho

Vinicije B. Lupis

Virgínia Soares Pereira 


\section{HUMANISMO E CIÊNCIA}

\section{Antiguidade e Renascimento}

ANTÓNIO MANUEL LOPES ANDRADE

CARLOS DE MIGUEL MORA

JOÃO MANUEL NUNES TORRÃO

(COORDS.)

AVEIRO • COIMBRA • SÃO PAULO

2015

UA EDITORA • UNIVERSIDADE DE AVEIRO

IMPRENSA DA UNIVERSIDADE DE COIMBRA

ANNABLUME 
OBRA PUBLICADA

COM A COORDENAÇÃO

CIENTÍFICA DE:

CENTRO DE LÍNGUAS,

LITERATURAS E CULTURAS DA

UNIVERSIDADE DE AVEIRO

CENTRO DE ESTUDOS

CLÁSSICOS E HUMANÍSTICOS DA

UNIVERSIDADE DE COIMBRA

CÁTEDRA DE ESTUDOS SEFARDITAS

"ALBERTO BENVENISTE"

DA FACULDADE DE LETRAS DA

UNIVERSIDADE DE LISBOA 


\section{SUMÁRIO}

PREFÁCIO

1.1 "Teofrasto, Tratado das plantas. No alvor de uma nova ciência" 13

Maria de Fátima Silva

1.2 "Francisco de Melo e os fragmentos de teoria óptica de Pierre Brissot" 21 Bernardo Mota

1.3 "Algumas reflexões sobre as pedras preciosas nos Colóquios dos simples de Garcia de Orta" 37 Rui Manuel Loureiro

1.4 "Estratégias, patronos e favores em Colóquios dos Simples de Garcia de Orta" 63 Teresa Nobre de Carvalho

1.5 "As plantas na obra poética de Camões (épica e lírica)" 95 Jorge Paiva

1.6 "Nicolás Monardes, John Frampton and the Medical Wonders of the New World" .141 Donald Beecher

1.7 "Literatura e Medicina: alguns textos de Justo Lípsio e de dois doutores Luís Nunes" 161 António Guimarães Pinto

1.8 "Ontologias e idiossincrasias dos Amantes, à luz da Archipathologia de Filipe Montalto" ...... 211 Joana Mestre Costa \& Adelino Cardoso

1.9 "Gabriel da Fonseca. A New Christian doctor in Bernini's Rome". .227 James W. Nelson Novoa 


\section{2) DIOSCÓRIDES E O HUMANISMO PORTUGUÊS: OS COMENTÁRIOS DE AMATO LUSITANO}

2.1 "Léxico científico português nos Comentários de Amato: antecedentes e receção"

Ana Margarida Borges

2.2 "Usos medicinais das plantas, em Amato Lusitano: o bálsamo"

António Maria Martins Melo

2.3 "Amato Lusitano e a importância da ilustração botânica no século xVI.

Em torno das edições lionesas das Enarrationes (1558)"

Carlos A. Martins de Jesus

2.4 "Sobre la identificación entre ébano y guayaco en una entrada

del Index Dioscoridis de Amato Lusitano".

Carlos de Miguel Mora

2.5 "Os partos distócicos em Amato Lusitano e em Rodrigo de Castro:

fontes, doutrinas e terapias greco-romanas"

\section{Cristina Santos Pinheiro}

2.6 "Do carvalho ao castanheiro: usos e propriedades medicinais

de fagáceas nas Enarrationes de Amato Lusitano".

Emília Oliveira

2.7 "O mundo mineral nos Comentários a Dioscórides de Amato Lusitano".

Isabel Malaquias \& Virgínia Soares Pereira

2.8 "Alguns comentários de Amato: entre a estranheza e a realidade"

João Manuel Nunes Torrão

2.9 "Caracterização e usos terapêuticos de produtos de origem marinha

nos Comentários de Amato Lusitano a Dioscórides"

José Sílvio Moreira Fernandes

2.10 "La mandrágora de Amato Lusitano: edición, traducción y anotación"

Miguel Ángel González Manjarrés

2.11 "O vinho e os vinhos - usos e virtudes de um dom dos deuses

nas Enarrationes de Amato Lusitano"

Telmo Corujo dos Reis

2.12 "Amatus Lusitanus e Didaco Pirro: due ebrei portoghesi

e cerchia umanistica di Dubrovnik" 481

Vinicije B. Lupis

2.13 "Estudos contemporâneos sobre Amato Lusitano". 513

João Rui Pita \& Ana Leonor Pereira 


\title{
Gabriel da Fonseca. A New Christian doctor in Bernini's Rome.
}

\author{
JAMES W. NELSON NOVOA ${ }^{1}$
}

\section{RESUMO:}

Esta comunicação apresenta novos dados, através da edição e análise de documentos arquivísticos, sobre o médico lamecense Gabriel da Fonseca (1586?-1668), professor de medicina nas universidades de Pisa e de Roma e médico pessoal do papa Inocêncio $X$. A documentação evidencia as diversas estratégias usadas por Gabriel da Fonseca para se integrar na Roma do séc. xVII. O seu estudo permite-nos compreender melhor as actividades do médico originário de Lamego nos anos em que aí viveu, a sua actividade mecenática em relação a Gian Lorenzo Bernini e os seus vínculos familiares, enfim, as estratégias usadas para alcançar uma inserção plena no tecido social romano do período barroco.

\section{PALAVRAS-CHAVE:}

Medicina; mecenato; cristão-novo; Portugal.

\section{ABSTRACT:}

This article presents new information, through the edition and analysis of archival documents, concerning the doctor from Lamego Gabriel da Fonseca (1586?-1668), a professor of Medicine in the Universities of Pisa and Rome and personal physician to Pope Innocent $X$. The documents demonstrate the different strategies used by Gabriel da Fonseca to integrate in the Roman society of the seventeenth century. Their study allows us to better understand the activities of this doctor from Lamego during the years in which he lived in Rome, his patronage of Gian Lorenzo Bernini and his family ties which all played into his strategies of insertion into the social world of Baroque Rome.

\section{KEYWORDS:}

Medicine; patronage, New Christian; Portugal.

1 Cátedra de Estudos Sefarditas «Alberto Benveniste»_Universidade de Lisboa: jwnovoa@gmail.com. 
At some point between 1662 and 1665 work was undertaken in earnest on a chapel in the Roman church of San Lorenzo in Lucina, which years later would known as the Cappella dell'Annunziata or more commonly, the Fonseca chapel, according to the design of Giovan Lorenzo Bernini (1598-1680), engaged in this enterprise by the physician from Lamego, in the north of Portugal, Gabriel da Fonseca (1586?-1668) ${ }^{2}$. The work in the chapel which is best known, and indeed, is associated with the name of its patron is a bust, which depicts Fonseca dressed in a doctor's robes, holding a rosary enrapt in a devotional pose and is rightly hailed by art historians as one of the pivotal works in the late production of the Neapolitan painter and sculptor. Few, however, have rarely delved into the complexities of the man behind the commission or what could have been, at least in part, the motives behind the decision to have himself and his family interred in the church. Here I will address some of these issues, relying on hitherto unpublished documents, chief among them Fonseca's will, in order to provide some background to man behind the construction of the chapel and how learning, medicine and patronage all played into the pursuit of social integration and ascendancy in Baroque Rome.

The work on the decoration of the chapel itself employed some of the most well known artists of the day. The altarpiece, a depiction of the Annunciation, the work of Ludovico Gimignani (1643-1697) was executed sometime before 1663 and the following year Ludovico's father, Giacinto (1606-1681), signed the painting of Elisha pouring salt into the waters of Jericho in order to purify them. The work on the chapel also involved the talents of other important artists of the moment such as Guillaume Courtois (1628-1679) who contributed a painting of King Ahab and the prophet Elija on Mount Carmel which is now lost and the sculptor Antonio Raggi (1624-1686) along with lesser known people active in Baroque Rome's artistic life. ${ }^{3}$

Suffice it to say that the initial design for the chapel itself can be dated around 1663, when Bernini was commissioned by Fonseca to undertake plans for its construction. ${ }^{4}$ Gimignani's altarpiece is central to the overall scheme of the chapel for which Fonseca had planned. The later addition of Bernini's bust of Fonseca, participates in the whole scene, almost seeming to face the event of the annunciation as though paying homage to the scene. ${ }^{5}$ The whole is a clear indication of Fonseca's attention to leaving a stamp on the church in the form of a chapel dedicated to himself and his

2 The most recent dating of the work on the chapel is to be found in Fabio BARRY, "New documents on the decoration of Bernini's Fonseca Chapel", The Burlington Magazine 146 (June 2004), pp. 396-399.

3 Ibid.

4 Giovanni CARERI, Bernini. Flights of Love, the Art of Devotion, trans. Linda LAPPIn. Chicago, The University of Chicago Press, 1995, pp. 11-22.

5 On the iconography in the chapel see Judy DoBIAS, "Gian Lorenzo Bernini's Fonseca Chapel in San Lorenzo in Lucina", The Burlington Magazine 120, no. 899 (Feb. 1978), pp. 65-71; Giovanni CARERI, "Il busto di Gabriele Fonseca nel "bel composto" di Bernini", in Augusto GenTILI, (a cura di), Il ritratto e la memoria, 3. Roma, Bulzoni, 1993, pp. 195-204; Giovanni CARERI, Bernini..., op. cit., pp. 11-22; Margaretha Rossholm LAGerlöF, "Life Transformed: Performative Meaning, Analogy, and the Art of Bernini's Funeral Decorations", Konsthistorisk Tidscrift 81 (2012), pp. 9-11. 
Portuguese family. His will, published here, indicates very clearly just how the chapel fit into an overall desire to commemorate, celebrate and ensure the ensconcing of his family in Rome, by providing a resting place for those of them who had already died and for those who were to die in the future.

Gabriel da Fonseca made out his will on March 27, 1668, before a notary and in the house of a lawyer, one Eusebii de Eusebiis. According to an autobiographical account he had prepared several years before, in 1657, for the University of Rome where he was employed as a professor of Medicine he was then over eighty years old. ${ }^{6} \mathrm{He}$ apparently had worked in that capacity for some twenty years, a position he was surely confirmed in thanks to his proximity to Popes Urban VIII (1623-1644) and Innocent X (1644-1655), having worked as a physician to the conclaves which elected both popes and for the latter from his election until Innocent's abrupt dismissal of Fonseca in 1654 and literally working until the year of his death, which occurred in December 1668. ${ }^{7}$ It was during his tenure as a professor of medicine in Rome that he prepared his autobiographical account, intended as an exercise in self-promotion in which fact and fiction easily overlap. In it he claimed to have been a permanent fixture in the Spanish community in Rome of the seventeenth century, linked to men of power in both the church and the state, in the employ of several Spanish ambassadors as their personal physician, chief among them Gaspar de Borja y Velasco (1580-1645) whom he followed on to Naples when he was viceroy there briefly. ${ }^{8}$ That a Portuguese physician should make such inroads into these

6 According to the account he was born in Lamego at the end of the month of February in 1586. The account is published in James Nelson NOVOA, "Medicine, learning and self representation in seventeenth century Italy. Rodrigo and Gabriel da Fonseca", in António ANDRADE, João TORRÃo, Jorge Costa, Júlio COSTA (orgs.), Humanismo, Diáspora e Ciência (séculos XVI e XVII): estudos, catálogo, exposição. Porto, CMP-BPMP; UA-CLC, 2013, pp. 227-229.

7 "12 dicembre 1668: Il signor Dottor Gabriele Fonsecha, portoghese in età di anni 63, figlio del quondam signor Diego dal medesimo loco, fu marito della quondam signora Caterina Comes romana, morì nella parrocchia di San Tomaso in Parione di subito et il suo corpo fu seppellito in questa nostra Chiesa il dì seguente." San Lorenzo in Lucina, Morti (vol. VII), 1668, fol. 19 r. Archivio Storico del Vicariato di Roma. This contradicts the date of Fonseca's death which has been given by Diogo Barbosa Machado of 20 May 1668. Diogo Barbosa MACHADO, Bibliotheca Lusitana, histórica, crítica e cronológica na qual se comprehende a notícia dos authores portugueses e das obras, que compuserão desde o tempo da promulgação da ley da Graça até o tempo prezente. Lisboa, na officina de Ignacio Rodrigues, 1747, tomo II, pp. 313-314.

8 On Spain and Rome see Thomas James DANDELET, Spanish Rome 1500-1700. New Haven, Yale University Press, 2001; Michael, J. LeVIN, Agents of Empire. Spanish Ambassadors in Sixteenth-Century Italy. Ithaca, Cornell University Press, 2005; Valentina Favarò, "Un hombre al servicio del rey: Francisco de Lemos, conde de Castro (1601-1620", Saitabi 60-61 (2010-2011), pp. 189-202; Isabel EnCISo, "La embajada de obediencia del VI Conde de Lemos: ceremonial diplomático y política virreinal", in Carlos José Hernando Sánchez (ed.), Roma y España. Un crisol de la cultura europea en la Edad Moderna. Vol. 1. Madrid, Sociedad estatal para la acción cultural exterior, 2007, pp. 471-513; David García Cueto, "Mecenazgo y representación del Marqués de Castel Rodrigo durante su embajada en Roma", in Carlos José Hernando Sánchez (ed.), Roma y España. Un crisol de la cultura europea en la Edad Moderna. Vol. 2. Madrid, Sociedad estatal para la acción cultural exterior, 2007, pp. 695-716; Silvano Giordano, "Gaspar Borja y Velasco rappresentante di Filippo III a Roma", Roma moderna e contemporanea 15, 1-3 (gennaio-dicembre 2007), pp. 157-186. 
Spanish contexts there should come as no surprise. From 1580 to 1640 Portugal found itself governed by the Habsburg monarchy of Spain under a shared crown. It was natural to try to curry favor with Portugal's overseers given the advantages these could bring to one in a place like Rome.

While he himself frequented the circles of Spanish power within the city he himself chose to marry a Portuguese woman. On September 14, 1618 he wed one Catarina Gomes, the daughter of António Gomes, from Elvas receiving a dowry of 4,000 julios and 500 scudi in property and goods. ${ }^{9}$ He chose to settle in the parish of San Tommaso in Parione, in the quarter in Rome where the Fonsecas from Lamego would first seemed to have settled upon arriving in Rome in the middle of the sixteenth century. One of them, António da Fonseca (1515?-1588), a prominent merchant-banker, had a family chapel built in the church of San Giacomo degli spagnoli, the national church of the Castilians in Rome, in Piazza Navona in 1583 in which he, his wife and son were buried. It was a tangible sign of the presence of the family hailing from the north of Portugal in the city. ${ }^{10}$

Perhaps in an effort to distance himself from the family which had preceded him in the Rome or from the Spanish church, especially after Portugal had gained its independence from Spain in 1640, other members of Gabriel's immediate family chose to be interred in San Lorenzo in Lucina. His sister, Violante, had chosen to be buried there, a wish which was manifested in her will, opened after her death in 1657 as her mother Isabel Cardoso, had been before. Both were buried in the church but awaiting a chapel which was to be built for the family, a project which Gabriel da Fonseca already was nurturing, according to Violante's will. ${ }^{11}$ It was shortly after his sister's death in fact that Gabriel requested the priests of the Clerics Regular Minor, the religious order which, since the beginning of the seventeenth century, had taken possession of the church, to have a family chapel built. They responded favorably in April 1661, allowing for a chapel to built and administered by the Fonseca family, in invocation of the Annunciation. ${ }^{12}$

At his death Gabriel himself was solidly in place in Rome, a figure known to all. He could flaunt the credentials of any well to do Romanized foreigner, becoming a Roman citizen in 1638, purchasing a villa in Frascati in 1640 and family palace in Parione, in 1653, in which he

9 The contract is published as doc. 2 in the documentary appendix.

10 On the Fonseca's in Rome see Susana Bastos Mateus and James Nelson NovoA, "A Sixteenth Century Voyage of Legitimacy. The Paths of Jácome and António da Fonseca from Lamego to Rome and Beyond", Hispania Judaica 9 (2013), pp. 169-192, and James Nelson NovoA, "Unicorns and bezoars in a Portuguese house in Rome: António da Fonseca's Portuguese inventories", Ágora, Estudos Clássicos em Debate 14.1 (2012), pp. 91-112; IDEM, "Gusti e saperi di un banchiere portoghese a Roma nel Rinascimento", Giornale di Storia 10 (2012) (http://www.giornaledistoria.net/index.php?Articoli=557D0 301220A740321070500777327).

11 Bruno ContARd, "Precisazioni sul Bernini nella cappella Fonseca", Studi di storia dell'arte 1 (1991), p. 275.

12 B. ContARDI, "Precisazioni...", op. cit., pp. 275-276. 
had built up a fine art collection. ${ }^{13}$ The fact that cardinals Benedetto Odescalchi (1611-1689) and Lorenzo Imperiali (1612-1673) are named the protector of his heirs in his will is a further indication of his integration in Rome and familiarity with important members of Roman society. Aside from his teaching and his practice of medicine to prestigious patrons he had gained renown as one of the advocates and users of quinine in Rome to treat malaria. His Roman career followed his university training (1603-1609) and teaching (1609-1611) in Pisa, to which he led by his prestigious uncle, Rodrigo da Fonseca (1550 ca-1622), the author of more than twenty medical works and a professor in Pisa (1575-1615) and later in Padua (1615-1622). ${ }^{14}$ These Tuscan years were evoked in Fonseca's 1657 autobiographical account and shortly after his death by his son, Gaspare, who, writing on December 22, 1668 to Granduke Ferdinando II de' Medici (1610-1670), in an obvious bid to ingratiate himself with him, informing of this father's recent death while he offered his Christmas greetings. ${ }^{15}$

\section{GABRIEL DA FONSECA'S LAST WILL AND PROVISIONS}

The existence of the will and itself and its contents have been known for some time, having been discovered by the art historian Irving Lavin in the late 1970's and having been subsequently alluded to and partially published by scholars who have worked on Fonseca's commission to Bernini. ${ }^{16}$ The provisions in the will were rendered public on December 12, 1668, the same day as his death. ${ }^{17}$ The terms of the will were carefully crafted so as to make sure his name and memory would be conserved and preserved in Rome as well as those of his offspring, doing all that was possible to have them make inroads into Roman society. It is a reflection of the important ties with that society that he had been able to establish, links which had been forged during the decades in which he had been recognized as a prestigious physician, linked to the Spanish political and ecclesiastical presence in the Eternal City and to the papacy. The document cites some of the members of the upper echelons of Roman society with whom Gabriel was in contact in a variety of capacities. It is a telling demonstration of the position of prestige which he had attained by the time of his death there.

13 B. CONTARDI, "Precisazioni...", op. cit., p. 276. On the villa in Frascati, obtained from his brother-in-law Luís Gomes see Maria Barbara Guerrieri Borso "Il 'palazetto' di Frascati. Il casino dei Gomez, Fonseca, Silva, oggi Mergè, opera di Francesco Peparelli", Palladio 43 (2009), pp. 104-110.

14 James Nelson Novoa, "Medicine, learning and self representation...", op. cit., pp. 216-219.

15 The letter is published as document 3 in the documentary appendix.

16 Judy Dobias, "Gian Lorenzo Bernini's...", op. cit., p. 65.

17 San Lorenzo in Lucina, Mort, v. VII, 1668, fol. 19R, Archivio Storico del Vicariato di Roma. I thanks my colleague Bruno Pomara Saverino for having transcribed this document for me. 
Judging from the information we can glean about them in the document all his children, presumably born in Rome, had all either made successful marital alliances or entered the Church. He had two daughters, one Antonia Fonseca Argoli, married to Prospero Argoli, and Olimpia Fonseca Galli, married with three boys and left them one hundred scudi each. Another, Isabella Fonseca, a religious at a convent in Campo Marzio, who took upon the name donna Maria Helena, was left one hundred scudi, a year. One son was a priest, Baldassarre Fonseca, a canon of Santa Maria Maggiore, to whom he left 20,000 scudi, in a censo shared with the Duke of Bracciano, along with investments in papal debt (Monti), allowing him, in addition, to live in Gabriel's house after his death. From the 1657 autobiographical account we learn that Baldassare had been made a knight of Saint Peter before the canonry in the Roman basilica and had been granted Spanish naturalization in order to receive ecclesiastical benefices in Spain. ${ }^{18}$ Another son, Gaspare Francesco Fonseca, is named as his universal heir.

Gaspare was entrusted with the administration of the family chapel which Gabriel had ordered to be erected, claiming, in the will, that it was to be amovibile ad nutum di Gaspare Francesco Fonseca mio figlio e suoi descendenti or, in lieu of him, his cleric son, Baldassarre and that it was to be administrated by his descendants. A mass was to be said each day in the chapel for his soul, that of his ancestors, wife, uncles, aunts, brothers and sisters and other relatives, preferably by a priest which is a member of the family. In addition four masses a month are to be said for the repose of the soul of his sister, Violante Fonseca, something which she had apparently established in her will, for which she had provided funds.

Yet it was not only in stone and through masses that he wanted to be remembered and evoked. His will provided detailed instructions to assure that the the Fonseca name would be passed on, insisting that Giuseppe, the son of a deceased daughter of his, Anna Fonseca, who had been married to one Ludovico Panizza, should maintain the Fonseca name and arms if he wanted to receive some of Gabriel's inheritance. The same provisions were made out to the oldest son of his daughter Olimpia Fonseca Galli. He had left his native land and made a name for himself through his hard work, meticulously organized self promotion and cultivation of important social relations. After his death he was concerned not only that his name and his activities be remembered but that the Fonsecas of Lamego remain in Rome, something which was to be obtained by doing all possible to perpetuate the family name. Gabriel had thus chosen Science, Medicine and social capital as a means to ensure that his New Christian family from Portugal could become Roman, all the while never forgetting his origins.

18 James Nelson Novoa, "Medicine, learning and self representation...", op. cit., p. 228. 


\section{DOCUMENTARY APPENDIX}

\section{Document 1}

Archivio Storico Capitolino di Roma, Trenta Notai Capitolini, Sez. 19, Not. J. B. Rondinus, Busta 56, Testamenta \& Donationes ab anno 1667 usque 1672.

Aperitio testamenti bone memorie Gabrielis Fonseche.

Die decima decembris 1668

Coram perillustri et excellentissimo domino Vincentio Candido, notario illustrissimi et reverendissimi domini alme Urbis gubernatoris in civilibus causis, locumtenente in Romana curia eiusque districtu, iudice ordinario et competente et ad interponendum decreta in contractibus voluntarie iurisdictionis a sanctissimo domino nostro papa specialiter deputato pro tribunali sedente super quadam sede lignea coramine ornata in loco infrascripto posita et existente, quam sedem et quem locum pro sitis iuridico et congruo tribunali, quoad hunc actum tantum valide peragendum elegit et deputavit, me notario ac testibus etc., presentes et personaliter constituti perillustris dominus Gaspar ac perillustris et reverendissimus dominus canonicus Baldassar, germani fratres de Fonsechis, filii bone memorie Gabrielis, mihi cogniti, asserentes nuper dictum dominum Gabrielem eorum patrem de hac ad meliorem vitam migrasse, prout ego notarius cum infrascriptiis testibus illius cadaver super quadam tabula extensum in propria eius domo vidi et recognovi, condito prius per eum testamento clauso et cosigillato et mihi etc. sub die 27 martii proximi preteriti consignato cum facultate illum, sequto eius obitu, aperiendi et publicandi, quod ego notarius pro manibus habebat sanum, integrum, illesum, nullaque in parte vitiatum, ideo predicti domini fratres de Fonsechis|stante obitu dicti bone memorie Gabrielis eorum patris ad hoc ut per eum disposita debite executioni demandentur, petirerunt et institerunt a dicto domino iudice dictum testamentum per me notarium aperiri et publicari mandari premisso et omni alio meliori modo etc.

Qui perillustis et excellentissimus dominus iudex ut supra sedens etc., auditis etc., cum iustum petenti non sit denegandus assensus, dictum testamentum aperiri, desigillari et publicari mandavit omnibus etc. prout ego idem notarius ad mandatum dicti domini iudicis utendo facultatibus mihi a domino quondam Gabriele in eiusdem testamenti consignatione attributis idem testamentum aperiri, desigillari, publicari et de verbo ad verbum perlegi tenori etc. in quibus omnibus et singulis tamquam rite, recte et legitime gestis et factis dictus dominus iudex suum ius suique officii iudiciariam auctoritatem pariter et decretum interposuit, supplendo si qui etc. et alterius quomodolibet folium eiusdem testamenti in principio et calce propria manu signavit et lineavit omni etc. rogante etc. 
Actum Rome, domi solite habitationis dictorum dominorum de Fonsechis in regione Parionis, presentibus perillustre et excellente domino Petro Andree soprano, filio quondam Ascanii Senogalliensi et illustri Francisco Carilli magistri Marci Romano testibus etc.

Die vigesimaseptima martii 1668

In mei etc. perillustris et excellentissimus dominus Gabriel Fonseca, filius bone memorie Didaci Lusitanus, medicus phisicus in Urbe mihi etc. cognitus, sanus Dei gratia mente, sensu, loquela ac visu, auditu et in-|tellectu ac etiam corpore, timens casum sue future mortis, cum nil (sic) sit certius ea nilque incertius hora et puncto illius volensque diem sui obitus testamentaria dispositione prevenire, deliberavit facere, prout fecit, suum ultimum nuncupativum testamentum quod de iure civili dicitur sine scriptis in presentibus foliis serio consuetis et septem sigillis sigillatis eius etc. propria manu, ut dixit, subscriptis et manu persone sibi fide scriptisque mihi etc. tradidit et consignavit, in eisque contineri dixit suum ultimum testamentum suamque ultimam voluntatem, quod et quam valere voluit iure testamenti nuncupativi sine scriptis, donationis causa mortis, codicillorum et alias omni etc. cassans, irritans et annullans omne aliud testamentum, codicillos et alias quasvis dispositiones per eum hactenus quemlibet forsan factas sub quibusvis verbis et derogatoriis vel derogatoriorum derogatoriis et hoc ceteris omnibus preferri et prevalere voluit non solum etc. sed omnibus tribuitque mihi facultatem illum statim sequuto eius obitu ad instantiam cuiusvis persone etc. aperiendi et publicandi propter auctoritatem et absque alicuius domini iudicis decreto premissis et alias omnibus super quibus etc.

Actum Rome, domi solite habitationis illustrissimi domini advocati Eusebii de Eusebiis in via Acqueductorum regionis Campimartii, presentibus infrascriptis testibus, nempe perillustre et admodum eccellenti domino Iohanne, perillustre Baptista Pasqualino filio quondam Philippi de Accumulo Ausculane diocesis, perillustre et adomodum excellente domino Paulo Mattheo, filio domini Laurentii Reatino, perillustre et admodum excellente domino Augustino Gri-|sono filio quondam Nicolai Romano, illustre et excellente domino Bonaventura Ciaffarello filio quondam Dominici de Ispello, Spoletane diocesis, illustre et excellente domino Alexandro Nerio filio domini Iohannis de Camaiono Luccensis diocesis, domino Francesco Maria filio quondam Bernardini Guasturini de Aretio in Etruria et magistro Bernardo de Carolis filio quondam Iohannis Luccensi testibus, qui sese propriis manibus subscripsere ut infra.

Io Giovanni Battista Pasqualoni fui testimonio quanto sopra etc.

Paolo Mattei fui testimonio

Io Agostino Grisoni fui testimonio

Io Bonaventura Ciaffarelli fui testimonio

Io Alessandro Neri fui presente etc. 
Io Francesco Maria Guastarini fui testimonio

Io Bernardo Carli fui testimonio

In Dei nomine amen. Anno salutis 1668, die vero vigesimaseptima mensis martii, tempore pontificatus sanctissimi in Christo patris domini nostri domini Clementis pape noni, anno eius primo.

Io Gabrielle Fonseca, figlio della bona memoria del signore Diego Luigi della città di Lamego di Portugallo, da molti anni in qua commorante in Roma, famigliare e medico secreto della felice memoria della santità di nostro signore papa Innocentio X e lettore già nello studio di Pisa, e al presente nella Sapienza di Roma publico lettore di pratica di medicina, sano per grazia di Dio, di corpo, mente, sensi, loquela et intellecto, sapendo che ogni creatura|nata deve morire e che nessuno può sapere l'hora et il giorno estremo della sua vita, ho voluto - mentre mi trovo in questo essere - disporre delli beni temporali concessimi da sua divina maestà in questa vita et ho deliberato di fare il presente testamento nuncupativo sine scriptis e perchè desidero che la mia dispositione non si sappia se non seguita la mia morte. Lo fo chiuso e sottroscritto [sic] di mia propria mano nel modo che segue.

E prima - con tutto il cuore — raccomando l'anima mia a nostro signore Giesù Christo supplicando humilmente che per l'infinita bontà e misericordia sua si degni farla degna delli meriti della sua santissima passione, e divotamente prego la gloriosissima vergine Maria madre di Dio, tutti li santi e angeli del cielo che sempre e nell'hora della mia morte intercedano per me.

Dopo che sarò morto voglio che il mio corpo sia seppellito nella venerabile chiesa di San Lorenzo in Lucina nella quale chiesa è sepellita la bona memoria della signora Isabella Cardosa Fonseca, mia carissima e dilettissima madre, e la signora Isabella Cardosa Violante Fonseca, mia dilettissima sorella, nella sepoltura della mia cappella della Santissima Annuntiata che nuovamente ho fatto construere e perfettionare, et ordino che quelle siano trasportate nella medesima sepoltura della mia cappella sudetta accedente il placet di chi occorre in quanto sia di bisogno, sopra la quale sepoltura si dovrà fare nella lapidell'inscrittione del mio nome, cognome, patria, età et anco specificare gl'honori e cariche concessemi dalla felice memoria di Innocenzo X e la lettura di pratica da me esercitata nella Sapienza di Roma. Volendo di più che il mio corpo sia trasportato in detta chiesa privatamente et in quella dovrà stare esposto con quella quantità di torcie e pompa funerale che parerà che parerà $[$ sic] alli miei heredi et essecutori testamentarii, alla quale chiesa lascio quel che di raggione li verrà per la sepoltura.

Item voglio e commando che nel giorno seguente della mia morte — non si potendo nel medesimo per impedimento di festa o altro - sia recitato in canto funerale il mattutino de' morti con le laudi e cinquanta messe de' defonti per l'anima mia in detta chiesa e di più cento altre messe basse in tutto e da distribuirsi ne' monasterii e chiese di Roma tra quelli, trenta 
nella chiesa della Pace et il resto in altre chiese o monasterii che pareranno a detti miei heredi et essecurtori testamentarii, fra le quali nel monasterio di San Gregorio e sua chiesa [et se] debbiano celebrare diece messe, di dette cento per l'anima mia come sopra.

Item voglio e commando che al trigesimo giorno della mia morte — non essendovi impedimento di festa che in tal caso voglio che sia il giorno seguente - si celebri in detta chiesa di San Lorenzo in Lucina un altro offittio de' morti|con le laudi e mattutino come sopra ordinato nel giorno della mia morte con venticinque messe basse per l'anima mia, de' mio padre, madre, zio, sorelle e parenti.

Inoltre dichiaro che doppo l'anno 1642 essendo partito di Roma doppo la morte della bona memoria di Luigi Gomez, suo fratello maggiore, e signore Ferdinando Gomez Estella, mio cognato, restando questi debitori della Camera per la Tesoreria di Portugallo da loro amministrata, io per loro di mia propria volontà per riparare alla subhastatione della loro villa di Frascati, pagai alla Reverenda Camera seimila scudi moneta in più volte - come costa dalle ricevute da lei fatte — e da poi pure in più volte due altri mila et ottocento scudi con la cessione delle raggioni di detta Camera e per li primi seimila scudi fu da me compra la villa di essi posta in Frascati cum pacto redimendi fra cinque anni che, non havendola mai riscossa in tanti anni, restò per me libera e, restando creditore di maggior somma per altri debiti per essi pagati ad altri creditori per sodisfatione di detti denari pagati, riscossi la pigione della casa posta a Sant Eustachio e li frutti di un lavatore che possedevano alla fontana di Trevi, havendo però pagato a donna Maria Susanna e a donna Maria Alessandra lıannue entrate assegnateli da essi fratelli e zii di detta donna Maria Alessandra, loro nipote, però ordino che, se a caso fossero creditori o debitori facendosi li detti conti, si aggiustino ancorchè io in coscienza non creda doverli cosa alcuna, anzi stimo essere|creditore, non volendo però cos'alcuna da loro per questo particolare, havendomi detto signor Ferdinando Gomez fatto con le sue lettere la dichiaratione di esser saldati et aggiustati li conti di dare et havere fra di noi, come apparisce dalle lettere e scritte che sono appresso il signore Gasparo mio figliolo.

Item dichiaro che, stando da molto tempo in qua in mia casa la signora Dionisia Gomez quale, volendo continuare in mia casa, ordino e commando si debba tenere nella forma che io la tenevo vivendo con li miei heredi amorevolmente e, non volendo loro tenere in casa overo non volendo hora tenere in casa lei stante, li debbano dare detti heredi - mentre vive - cinque scudi il mese per l'amorevolezza che sempre ha usato meco, alla quale non voglio se li domandino conti di quello che ha tenuto in mano, ma si stia a quello che lei dirrà et tantomeno havendoci io revisti li conti che stanno benissimo e ne sono restato sodisfattissimo et io adesso per allhora li fo piena et assoluta quietanza e mi chiamo totalmente sodisfatto di quanto essa dirà.

Item dichiaro che ho due figlie maritate, una cioè la maggiore chiamata Antonia Fonseca Argoli, maritata al signor Prospero Argoli senza figlio, quale ha havuto seimilla scudi di moneta 
consegnateli in tanti luoghi de' monti, e l'altra si chiama Olimpia Fonseca Galli, la quale si trova con tre figli maschi: per la loro amorevolezza lascio ad esse Antonia et Olimpia, mie figliole, cento scudi a ciascheduna di loro per una sol volta|et in questi scudi cento l'instituisco heredi e voglio che non possino pretendere altro dalla mia heredità, se non quanto da me sarà disposto nel presente testamento et, in evento che non si acquietassero a questo mio testamento, ma che oltre alle cose da me disposte volessero molestare li miei heredi et heredità, in tal caso privo le medesime e chi di loro contraverrà, non solo nel presente legato, ma ancora dell'infrascritte sostitutioni havendole io in vita condecentemente dotate.

Item dichiaro e voglio che, in caso che la sudetta signora Antonia, mia figlia maritata al signore Argoli, restasse vedova con la sola dote di scudi seimila che io li diedi et il quarto dotale, perchè non gli basterà a vivere et a mantenersi conforme al suo grado, voglio che li miei heredi gli diano ogni due mesi anticipatamente la rata parte di cento scudi moneta l'anno che ci lascio mentre viverà e non oltre, e questo legato non habbia luogo quando il suo marito li lasciasse qualche simile portione.

Item dichiaro havere un'altra figliola chiamata al secolo Isabella Fonseca et al presente monaca in Campo Marso, professa, che hora si chiama donna Maria Helena alla quale, mentre si fece monaca, consegnai sessanta scudi l'anno d'entrata mentre viveva per li suoi bisogni et hora titulo institutionis et in ogn'altro miglior modo e titolo voglio e commando che, dopo la mia morte, se li ereschino $[s i c]$ quaranta scudi di moneta l'anno che in tutto saranno scudi cento di moneta l'anno mentre vive e non più oltre, e se li assegnino mentre vive detti scudi cento in tanti frutti de' luoghi de' monti esigibili od pighioni di botteghe o altra entrata|esigibile come ad essa più parerà e piacerà, dando ad essa donna Maria Helena amplissima facoltà di poterne pigliare subbito il possesso et esigere et far esigere tutta detta somma ogni anno mentre vive di sua propria auctorità et, in evento che i luoghi de' monti fossero estratti o ridotti, se li debbiamo assegnare altri, in modo che sempre abbia pieni et intieri li cento scudi l'anno e, seguita la mia morte, voglio che di più se li diano scudi centomila per una sola volta con espressa prohibitione che nè lei nè il monastero possi alcun'altra cosa pretendere dalla mia heredità per qualsivoglia ragione e di legittima o per supplemento di essa, perchè così voglio e dispongo in questo et in ogn'altro miglior modo.

Item dichiaro che, havendo io un altro figlio ecclesiastico chiamato Baldassare Fonseca, canonico di Santa Maria maggiore, titulo institutionis et in ogn'altro miglior modo lo lascio et instituisco parimente herede nella somma di scudi ventimila durante la sua vita solamente e non più, e questi scudi ventimila li dovrà pigliare parte in censo che ho con il signore duca di Bracciano, e parte in tanti luoghi de' monti - cioè del Sale e della Fede - tantum ipsius vita durante, con conditione però che del frutto deli detti ventimila scudi debba dare per mantenimento delle spese della casa quattrocento scudi l'anno, quali debbono essere per la parte al medesimo spettante, al quale parimente lascio che habiti nella casa mia e se li dia il suo appartamento dove al 
presente habita con le sue stanze che hora gode e, bisognando altre commodità nell'appartamento di sopra principalmente se entrasse in prelatura, se le diano le due stanze nell'appartamento di mezzo, restando la sala commune/e dichiaro che li quattrocento scudi sopradetti serviranno per il vitto e servitù et altre spese, eccetto che per le carozze e cochieri voglio che ogn'uno proveda alle sue con le proprie entrate, pregando detto Baldassare, mio figlio, voglia approvare e ratificare questa mia ultima volontà et alla medesima quietarsi senza contradittione alcuna et in ogni miglior modo, volendo e commandando di più che, nascendo qualche differenza o lite tra essi miei figli, non debbano in alcun modo litigare, ma che ogni differenza venghi decisa dalli monsignori due auditori di Rota spagnoli che pro tempore saranno in Roma e, se non vi fossero o non volessero fare questa parte, si rimetta la differenza a quel che deciderà monsignor decano della Rota opure, se così li parerà al signore avocato Eusebio, quali estragiuditialmente faranno gratia di acquietare ogni interesse di lite e pretensione senza proporle in Rota, dandoli per quest'effetto ogni facultà paterna e di arbitratori et amicabili compositori, imponendo et espressamente commandando a detti miei figli che debbano stare taciti e contenti a quel che sarà da detti signori lodato et arbitrato et, in evento che esso Baldassarre non volesse restar quieto e sodisfatto a questa mia dispositione, ma che volesse pretendere la legitima, adesso per allhora l'instituisco in essa legitima, ordinando espressamente che non possi pretendere altro dalla mia heredità per qualsivoglia causa e prestesto.

Item alla mia cappella della Santissima Annuntiata, posta nella venerabile chiesa di San Lorenzo in Lucina, lascio che si eregga una capellania amovibile ad nutum di Gaspare Francesco Fonseca mio figliole suoi descendenti in infinito et in difetto di esso signore Gaspare proveda detta cappella l'altro mio figlio Baldassarre e questi ancora mancando debbano provedere tutti gli heredi che succederanno nella mia heredità sino che ve ne saranno, e detta cappella sia sempre ad eorum nutum, amobivile, perpetua con entrata di scuti trentasei moneta da assegnarsi da me e, caso ciò non succedesse, se li assegni subbito dall'infrascritto mio herede con conditione che il sacerdote che terrà detta cappella dica ogni giorno una messa per l'anima mia de' miei ascendenti, di mia moglie, zii e zie, come anco di fratelli e sorelle e poi d'altri miei parenti, e voglio però che se vi sarà qualche sacerdote parente mio o de' miei heredi e di tutti li sostituti in questa eredità, debbano essere eletti e preferiti ad ogn'altro e di più voglio e dichiaro che nelle sudette messe si comprendano le quattro messe il mese che ho fatto celebrare per il passato sino al presente in esecutione di una lascita fatta dalla bona memoria della signora Violante Fonseca, mia sorella, per l'anima sua nel suo testamento, nel quale lascia che dette messe si comprendano in quelle che io lasciarò per l'anima mia in detta mia cappella e, quando non vi fosse nel suo testamento, voglio che siamo comprese in queste messe che io lascio quotidiane nella mia cappella e non si possino più pretenedere le dette quattro messe stante questa compretensione da me ordinata in questo testamento. 
Item ad una figlia del signor Ludovico Panizza chiamata Agata, che sta in educatione nel monastero di Campo Marzo, maritandosi o|monacandosi gli lascio scudi cinquecento moneta per una sol volta che gli servì per agiuto di dote.

Item lascio alla signora Gratia Gomez Checci, commorante in Terni mia nipote carnale, scudi cento moneta per una sol volta e, maritandosi una figlia che ha, li lascio scudi duecento per aiuto, il che voglio se li dia anche monacandosi.

Item lascio a tre sorelle del signor Ferdinando Gomez, residenti in Fiorenza monache nell'istessa città due in un monastero, l'altra nel monastero dell'Ape fuori di Fiorenza scudi trenta per ciascheduna di esse, e questo una sol volta acciò preghino Dio per me.

Item lascio ad Angelo Gomez e Gerolamo Gomez, miei nepoti carnali, luoghi cinque de' monti Camerali non vacabili e della Fede o Sussidio Quarto ad elettione del mio herede, i frutti de' quali luoghi siano la metà per uno d'essi Angelo e Girolamo e mancando uno, succeda l'altro e, se in caso ambedue loro mancassero senza figli legitimi e naturali, dichiaro che li detti scudi cinquecento con li frutti tornino al mio infrascritto erede Gasparo o suoi figli legittimi e naturali che, se a caso non vi fossero detto Gasparo e suoi figli nè Baltassarre, mi contento che detti miei nepoti Angelo e Girolamo Gomez ne siano legitimi padroni e dispositori, intendendo in questo caso non solo de' frutti, ma anco della sorte principale de' luoghi de' monti.

Item lascio che l'offitii vacabili e luoghi de' monti vacabili di S.|Spirito che sono a dispositione mia si debbiano fra sei anni vendere e comprarne tanta entrata non vacabile o in luoghi de' monte Camerali o in censi o altri stabili boni, non intendendo però di quelli offitii che sono alla dispositione de' miei figli, compri da loro, de' quali voglio che ogn'uno di essi che li haverà compri n'habbia il pieno et assoluto dominio senza haverne a dare ricompensa alcuna all'altro fratello che non n'havesse compri.

Item lascio a due miei nepoti carnali, figlie della bona memoria della signora Anna mia sorella, monache in Santa Susanna che si chiama una donna Maria Teresa e l'altra donna Maria Deodata, scudi dodeci l'anno tra tutte due, cioè scudi sei per ciascheduna di loro che, con altri dodeci lasciateli dalla bona memoria della signora Violante, sono ventiquattro e questi durante la lor vita e non altrimenti e, caso che una di loro mancasse, voglio che questo mio legato ritorni all'altra, e mancando ambedue ritorni all'infrascritto mio herede, non volendo che il monastero possa havere alcuna pretensione.

Item lascio alli servitori che si trovaranno in casa per una sola volta scudi diece moneta, et a Giovanni Maria, quale per molto spatio di tempo ha servito in casa, benchè di presente non serva, lascio scudi quindeci ritrovandosi però in Roma e questi per una sol volta, et a Giovanni Battista, cocchiero vecchio che mi serve, scudi venti per una sol volta ancorchè non si ritrovasse al|servitio e, caso fosse morto, voglio che detta quantità di scudi venti si diano alla sua moglie che seli goda assieme con i suoi figli, et agli altri cocchieri che si trovaranno al servitio 
di casa lascio scudi diece per una sola volta, et al signore Michelangelo, bracciero della signora Catarina, ritrovandosi al servitio lascio, scudi quindeci per una sol volta.

Item lascio che in tutti e singuli miei beni tanto mobili come stabili, raggioni, crediti, luoghi de' monti, nome de' debitori et attioni in qualsivoglia modo e luogo posti et esistenti appartenenti a me testatore e sotto qualsivoglia titolo spettanti et in avvenire mi potessero spettare et appartenere, sia et essere debba mio universale herede Gasparo Francesco Fonseca, mio figlio legitimo e naturale, e per tale l'instituisco e di propria bocca nomino, al quale sostituisco in infinito et in perpetuo per conservatione della mia casa Fonseca li suoi figlioli maschi, legitimi e naturali e dal proprio corpo nati in infinito, sempre con questa qualità e non altrimenti, volendo che in detti figlioli maschi e descendenti in infinito si conservino sempre i miei beni nella famiglia mascolina Fonseca senza potersi mai alienare in alcun tempo fuor di quella parte alcuna benchè minima della mia heredità et ciò per qualsivoglia urgente o urgentissima causa et ogni alienatione, etiam late sumpto vocabulo, sia nulla e di nessuna fermezza anzi possa da chiamati successivamente dopo l'alienante rivocarsi con facoltà di poterne prender possesso, etiam senza decreto di giu|dice e di propria autorità, dichiarando che questa prohibitione sia repetita eque pricipaliter et de per se in tutti quelli che possederanno la mia heredità in infinito et aggiungendo che l'alienante sia e si intende privato ipso facto et ipso iure alienando in tutto $\mathrm{o}$ in parte da quella portione e parte della mia heredità che alienarà, e questo perchè sempre interamente si conservi nei chiamati a questo mio perpetuo fideicommisso.

Item dichiaro e voglio che la villa di Frascati, trovandosi a vendere per giusto prezzo, si possi vendere et investire il prezzo o in altra vigna in Roma o suoi suburbii pure di giusto prezzo o in luoghi de' monti o in altri stabili di giusto prezzo $^{19}$ e, non vendendosi, possino i signori Gaspare e Baldasssarre andarci a dimorare egualmente. Il frutto però di essa spetti al signore Gaspare, al quale toccarà la spesa del mantenimento di essa villa.

E morendo in qualsivoglia tempo Gasparo Francesco Fonseca, mio figlio, senza figli legitimi e naturali e di proprio corpo nati voglio che, essendoci di detto Gaspare figlie femine legitime e naturali, succedano esse et i detti loro figlioli maschi legitimi e naturali e di loro proprio corpo nati et $\mathrm{i}$ loro descendenti in infinito in stirpes et non in capita con questo, che siino obligati ritenere il cognome et arme della famiglia Fonseca senza misura di altro cognome et arme, e quello possino mai lasciare anche con dispensa del principe, volendo in tal caso che decadano dalla mia heredità e vada come disporrò a quelli che osservaranno la mia volontà, cioè all'altri maschi delle femine sudette descendenti et, in difetto loro, come sostituirò appresso e, mancando le sudette figlie|femine del detto signore Gasparo Francesco, mio figlio, senza figlioli maschi come sopra, sostituisco e voglio succedano le di loro figlie femine legitime e naturali nate e da nascere di loro proprio corpo e loro descendenti in infinito maschi sempre in stirpes

19 prezzo added in at the margin. 
et non in capita con li pesi sudetti del cognome et arme della casa Fonseca come ho detto con questo che sempre siino preferiti i maschi in concorso et in difetto di maschi le femine e mancando Gasparo, mio figlio, senza figli legitimi e naturali tanto maschi quanto femine come sopra e loro descendenti finita la sua linea masculina e feminina e loro descendenti come sopra, opur morendo esso Gasparo senza figli legitimi e naturali, in tal caso sostituisco e voglio che succeda prima nell'usufrutto e nella proprietà ancora il sopradetto mio figlio Baldassarre Fonseca sua vita durante e doppo la di lui morte, o anche premorendo a Gasparo Francesco Fonseca, mio figlio, detta mia heredità e beni tanto nell'usufrutto come nella proprietà, voglio che succedano e sostituiscano tanto a Baldassarre quanto a Gaspare Fonseca tanto a' maschi quanto a' femine come sopra chiamati et ultimo di loro per la metà il figliolo maggiore d'età della buona memoria di Anna Fonseca, mia figliola maritata al signor Ludovico Panizza che si chiama signor Gioseppe, e per l'altra metà li figlioli maschi del signor Francesco Galli e loro descendenti maschi in infinito con le medesime conditioni come sopra, volendo che sempre uno di loro, cioè il figlio sudetto di detto signore Panizza come dal signore Galli e loro descendenti chiamati a questa mia heredità in|infinito, debba portare il cognome et arme della casa Fonseca e, mancando qualcheduno di loro, voglio che succeda l'altro con dette conditioni e, mancando loro maschi, succedano le femine e loro descendenti in infinito con le sopradette conditioni e, mancando loro maschi, succedano le femine e loro descendenti in infinito con le sopradette conditioni, salva sempre la prerogativa del sesso mascolino in stirpe e non in capita, con li medesimi pesi di arme e cognome come sopra nella metà che li toccarà e, mancando li maschi e femine tanto del signor Panizza come del signor Galli da me chiamati e, finita la linea di essi, succedano gl'altri sempre in stirpes et non in capita reciprocamente e, caso della total mancanza dell'una e dell'altra linea tanto mascolina quanto feminina in infinito, mancando in qualsivoglia tempo la linea de' Galli e di Panizza tanto de' maschi come de' femine, voglio che succedano et habbiamo la mia heredità li figlioli della bona memoria della signora Anna Fonseca e loro descendenti in infinito come sopra con l'istesso peso e conditioni che si impone agl'altri. Chiamando Girolamo et Angelo Gomez suoi figli maschi e descendenti in infinito come sopra et in difetto de' maschi le femine e descendenti delle femine in infinito sempre prima li maschi et in difetto di essi le femine come sopra, et in mancanza di tutti li sopranominati, sostituisco li figlioli e descendenti in infinito come sopra della signora Gratia Gomez Checci figlia di detta signora Anna, maritata già in Terni, con i medesimi ordini e pesi che sopra sempre in|stirpes et non in capita.

Item voglio e dichiaro che, in evento che il signore Giovanni Panizza altro figlio del signore Ludovico Panizza mio genero applicasse alli studi e vivesse con rettitudine con ubbidienza al padre e nel modo che conviene ad un buon gentilhomo, in tal caso lo sostituisco ugualmente con il fratello e, se in lui concorrino tali qualità, la dichiaratione la rimetto alla bontà et arbitrio di monsignor decano pro tempore della Rota et delli due signori auditori di Rota spagnoli, se 
vi saranno in Roma o chi di essi votarà pro tempore, e questa dichiaratione la possino fare e disfare più e diverse volte e quante bisognerà e che altro arbitrio e dichiaratione si stia tante volte quante occorrerà.

Item ordino e dichiaro e voglio che la prohibitione dell'alienatione da me sopra fatta sia e s'intenda nel più stretto modo che far si possa per conservare li beni nei chiamati al fideicommisso e, perchè si conservino integri e senza diminutione alcuna in perpetuo, volendo che s'intenda etiam late sumpto vocabulo e che sotto nome d'alienatione venga etiam de locatione ad longum tempus hipoteca, pegno et ogn'altra e, perchè so che per nulla di meno si trovano pretesti e colori per defraudare la mente de' testatori, dispongo che li miei heredi e ciaschuno di essi e tutti quelli che possederanno la mia heredità per mia ordinatione e dispositione|non possino vendere nè li frutti durante la lor vita, nè la commodità, nè altro quantunque minimo, particolarmente ne' luoghi de' monti, case et altri effetti esistenti in Roma, volendo che chiunque contrafarrà alienando li frutti o commodità alla vita del medesimo o in altro minor tempo sia e s'intenda irremissibilmente decaduto e privato ipso facto et ipso iure da ogni commodo della mia heredità, la quale spetti alli chiamati doppo di essi e, venendo il caso che li chiamati fossero figlioli de alienante, voglio e dichiaro che durante la vita dell'alienante e contraveniente quelli non devano essere ammessi, ma subentrino gli altri chiamati quali, venendo la morte dell'alienante, siano tenuti restituire a detti figli e più prossimi dell'alienante e non altrimenti, e questo senza eccetione alcuna, dando facoltà di pretendere possesso propria aucthoritate etiam senza decreto di giudice.

Item voglio, ordino e commando che ciascheduno de' miei heredi che vorrà succedere nella mia heredità, sia obligato fare inventario distinto di tutti li miei beni, mettendo la quantità etiam con la misura da farsi da un perito da elegersi da monsignor decano della Rota, notando tutti li confini distintamente et ogn'altra dimostratione e questo inventario debba farsi da ciaschuno che succederà quante volte la mia heredità passarà da uno in altro, volendo|di più che detto inventario debba dentro il termine di due mesi esser compito et esibito nell'archivio Urbano e, perchè questo non si trascuri e non si dia caso che li possessori della mia heredità alleghino ignoranza, voglio che siano obligato ciascheduno di loro che succederà obligarsi di ostentare tutto il contenuto in questo testamento che dovrà legersi et inserirsi de verbo ad verbum dell'obligo solenne e giustamente da farsi et effettuarsi avanti con l'assistenza di monsignore decano della Rota pro tempore quale prego a voler prendere questo peso.

Supplico l'eminentissimi signori cardinali Odescalchi et Imperiale a degnarsi d'esser protettori de' miei heredi e sostituti, supplicandoli degnarsi ad accettar un quadro per ciascheduno di loro da darseli dal signor Gaspare, mio figliolo et herede.

Essecutori di questo mio testamento e dispositione nomino e lascio il signor Eusebio Eusebii, avvocato concistoriale e de' poveri, e monsignor Giacomo Emense, nuovo auditore di Rota, 
eletto ultimamente e nepote di monsignor Giovanni Emense, alli quali tre lascio parimenete un quadro per ciascheduno di loro da darseli dal detto signor Gasparo mio figlio et herede.

Item voglio et ordino che li miei heredi e sostituti sudetti siano obligati ogni anno la vigilia della santissima Annunziata a dare in mano del sacristano pro tempore di San Lorenzo in Lucina acciò alla detta mia cappella dell'Annuntiata si possa|mantenere la lampada accesa scudi quattro moneta l'anno et inoltre in detta vigilia lascio per la detta mia cappella sei candele d'altare.

E questo voglio che sia il mio ultimo testamento et ultima volontà quale voglio che vaglia per ragione di testamento nuncupativo sine scriptis e, se per detta ragione non valesse, voglio che vaglia per raggione di donatione causa mortis o per raggione di codicilli per ultima volontà et in ogn'altro miglior modo, cassando, annullando ogn'altro testamento, codicilli e qualisivoglia ultima volontà sino al presente giorno da me fatta etiam se fosse con qualsivoglia clausola derogatoria e derogatorie di derogatoria per qualsivoglia notaro rogato et in fede l'ho fatto scrivere a persona a me fida e poi l'ho sottoscritto di mia propria mano.

Io Gabrielle Fonseca testo e dispongo come sopra manu propria

Ego Vincentius Candidus interfui ut supra

Iohannes Baptista Rondinus notarius rogatus 


\section{Document 2}

Archivio di Stato di Roma, Trenta Notai Capitolini, Not Q, Prot. 129, fols. 290r-291r. Acta spo(n)salia ill(ustrem) d(ominam) [Catherinam] Gomez et ill(ustrem) dominum Gabriele(m) Fonsecca(m)

Die 14 septembris 1618

In mei etc. presentia personaliter constitutus illustris Antonius Gomez Sueri quondam domini Gomez Philippi, pater et legitimus administrator illustris domine Catherine Gomez eius filie legitime et naturalis ex illustri domina Anna Fonseca coniuge procreata, vice et nomine dicti illustris domine Catherine ex una et illustris dominus Gabriel Fozecca Lamacensis partibus ex altera que partes sponte etc. omni meliori modo etc. devenerunt ad actum parentele et pacta sponsalia in Dei nomine pactata et stabilita in hunc modum (videlicet).

Dictus illustris dominus Antonius pater et legitimus administrator predicte illustris domine Catherine eius filie legitime et naturalis promisit predicto illustri domino Gabrielli presenti et acceptanti se facturum et curaturum omni exceptione remota quod dicta illustris domina Catherina eius filia legitima et naturalis previis denunciis ex forma Concilii Tridentini requisitis accipet in eius et legitimum sponsum dictum illustrem dominum Gabrielem et cum eo contrahet matrimonium de presenti vis et volo iuxta ritum Sancte Romane Ecclesie.

Et vice versa presentis illustris dominus Gabriel promisit presenti illustri domino Antonio patri et legitimo administratori predicte domine Catherine presenti et pro ea acceptanti previis dictis denunciis ex forma Sacri Concilii Tridentini requisitis accipere eius in veram et legitimam sponsam dictam illustrem dominam Catherinam et cum eam matrimonium contrahere per verba de presenti vis et volo iuxta ritum Sancte Romane Ecclesie.

Cui illustri domino Gabrieli presenti et acceptanti predictus illustris dominus Antonius pater et legitimus administrator predicte illustris domine Catherine pro illius dote promisit et convenit scuta quatuor milia monete ad iulios $\mathrm{x}$ pro scuto in pecunia numerata et alia scuta quingenta similia in tot bonis mobilibus extimatis quam dotem ipse illustris dominus | Antonius solvere et respective assignare ac tradere promisit hoc modo videlicet: scuta quingenta in tot mobilibus extimatis tempore quo ipse illustris dominus Gabriel eamdem illustrem dominam Catherinam eius futuram uxorem ad eius domum traducet et residuum in pecunia numerata infra duos menses a die consumationis matrimonii decurrentes libere.

Declarans tamen ipse illustris dominus Antonius in huiusmodi dote comprehendi debere legatum scutorum .600. vel .800. eidem illustri domine Catherine factum per illustrem dominam Violantem de Fonseca in suo ultimo testamento ut dixit rogato in civitate Pisarum per publicum notarium. 
Et convenerunt dicti illustres domini contrahentes quibus supra respective nominibus quod inter dictos futuros coniuges censeatur et sit facta donatio propter nuptias iuxta formam statuti urbis super lucratione, quibus ambe partes se subiecerunt et supposuerunt.

Quam dotem unam cum donationem propter nuptias aliisque variis dotalibus predictus illustris dominus Gabriel ex nunc pro tunc secuta solutione et satisfactione et pro ea summa que sequetur cautelavit et assicuravit in et super omnibus et singulis suis bonis mobilibus, immobilibus, iuribus, actionibus et nominibus debitorum presentibus et futuris ubicumque existentibus et extituris dictaque bona et iura similiter ex nunc pro tunc tam in genere quam in specie ita tam quod specialitas generaliter non deroget nec extra obligavit et hipotecavit eamdem dotem unam cum donatione propter nuptias aliisque iuribus dotalibus reddere et restituere promisit eidem illustri domine Catherine vel suis etc. aut cui vel quibus de iure restitutio facienda erit libere. |

Dans et concedens eidem illustri domine Catherine suisque etc. ac cui vel quibus restitutio facienda erit plenam licentiam et omnimodam potestatem, facultatem et auctoritatem in quocumque casu restitutionis dotis constante vel soluto matrimonio capiendi et apprehendendi realem, corporalem et attualem possessionem dictorum bonorum et iurium propria auctoritate sine alicuius iudicis vel curie licentia, decreto vel mandato aut vitio spolii seu iurium suorum lesione captamque et apprehensam retinendi et continuandi usque quo eidem illustri domine Catherine vel suis etc. aut cui vel quibus restitutio facienda erit de dicta dote donationeque propter nuptias aliisque iuribus dotalibus fuerit integre satisfactum et donec ipse illustris dominus Gabriel pro se suisque etc. constitutis etc. que omnia etc. alias etc. de quibus pro quibus se ipso etc. eorumque heredes etc. de bona etc. in ampliori forma Camere Apostolice cum clausulis etc. citra etc. ad invicem obligavit etc. renuntiandum approvationi etc. consentientes in mandatum executivum unica citatione precedente relaxandum etc. iuravit tactis etc. super quibus etc.

Actum Rome domi solite habitationis dicti illustris domini Antonii regionis predictis, presentibus domino Ludovico filio domini Angeli Picchi de Peschio Terre Marsicane diocesis planellano in Urbe apud ecclesiam Beate Marie de Pace et domino Johanne Baptista filio domini Matthie Cospini Anconitano testibus etc. ex quibus illustris Antonius est mihi notus. 


\section{Document 3}

Archivio di Stato di Firenze, Mediceo del Principato 1082, fol. 1533.

22 dicembre 1668

Serenissimo Signore et patrone mio illustrissimo.

Gli effetti d'una devota et ossequiosa gratitudine mi rendono ardito dar parte a Vostra Altezza Serenissima della morte della bona memoria di Gabbriello Fonseca, mio padre, che dal principio della sua gioventù sino all'ultimo della sua vita fu continuamente honorato dal serenissima sua casa. Partì dall'Amego (sic), sua patria, nel Regno di Portogallo, chiamato in Fiorenza da Rodrigo Fonseca, suo zio, lettore primario di medicina prattica nella celebre università di Pisa, et medico della gloriosa memoria del Gran Duca, Ferdinando, avo di Vostra Altezza Serenissima. La sorte del zio fu ben tosto communicata al nipote, vinendo provisto d'una lettura di filosofia nel medesimo studio: e si come in ogni loco ambidue goderno di continui honori conferitili dall'innata e somma generosità e beneficenza degli antenati e fratelli e di Vostra Altezza Serenissima, così vive sempre conservarne le rimembranze di ricevuti benefiti. Assalito questo ultimo pochi giorni sono da un improvviso accidente, passò a miglior vita et io come figlio et erede delle innumerabili obligationi del Padre ambisco et devo esserne perpetuo fortunatissimo debitore a Vostra Altezza Serenissima, suplicandola assieme del suo stimatissimo e gloriosissimo patrocinio Vostra Altezza Serenissima come sole egualmente benefico non sdegnarò conferire il lume delle sue gratie a servire, benché inutili et in tutto inhabili. Retribuisca, sua Divina Maestà, con concedere a Vostra Altezza Serenissima tutte le imaginabili proprietà, contentezze come con l'intimo del mio core gl'auguro in queste santissime feste natalizie di Nostro Signore Giesù Cristo che dopo molti e molti lustri e perpetuata per molti secoli la sua gloriosa prosapie dispensi a Vostra Altezza serenissima in questa vita il fonte di tutte le contentezze e poi l'aeterna gloria nell'altra compatisca Vostra Altezza Serenissima la mia temerarietà humilmente vivenendola et bacionadoli il lembo delle sue sue gloriose porpore rimango di Illustrissima Altezza Serenissima.

Roma, li 22 xbre 1668.

Humilissimo Devotissime et Obbligatissimo servitore.

Gasparo Fonseca. 


\section{BIBLIOGRAPHY}

Barry, Fabio, "New documents on the decoration of Bernini's Fonseca Chapel", The Burlington Magazine 146 (June 2004), pp. 396-399.

Careri, Giovanni, "Il busto di Gabriele Fonseca nel "bel composto" di Bernini", in Augusto Gentili (a cura di), Il ritratto e la memoria, 3. Roma, Bulzoni, 1993, pp. 195-204.

Careri, Giovanni, Bernini. Flights of Love, the Art of Devotion, trans. Linda Lappin. Chicago, The University of Chicago Press, 1995.

Contardi, Bruno, "Precisazioni sul Bernini nella cappella Fonseca", Studi di storia dell'arte 1 (1991), pp. $273-283$.

Dandelet, Thomas James, Spanish Rome 1500-1700. New Haven, Yale University Press, 2001.

Dobias, Judy, “Gian Lorenzo Bernini's Fonseca Chapel in San Lorenzo in Lucina”, The Burlington Magazine 120, no. 899 (Feb. 1978), pp. 65-71.

Enciso, Isabel, "La embajada de obediencia del VI Conde de Lemos: ceremonial diplomático y política virreinal”, in Carlos José Hernando Sánchez (ed.), Roma y España. Un crisol de la cultura europea en la Edad Moderna. Vol. 1. Madrid, Sociedad estatal para la acción cultural exterior, 2007, pp. 471-513.

Favarò, Valentina, "Un hombre al servicio del rey: Francisco de Lemos, conde de Castro (1601-1620", Saitabi 60-61 (2010-2011), pp. 189-202.

García Cueto, David, "Mecenazgo y representación del Marqués de Castel Rodrigo durante su embajada en Roma”, in Carlos José Hernando Sánchez (ed.), Roma y España. Un crisol de la cultura europea en la Edad Moderna. Vol. 2. Madrid, Sociedad estatal para la acción cultural exterior, 2007, pp. 695-716.

Giordano, Silvano, "Gaspar Borja y Velasco rappresentante di Filippo III a Roma", Roma moderna e contemporanea 15, 1-3 (gennaio-dicembre 2007), pp. 157-186.

Guerrieri Borsoi, Maria Barbara, "Il 'palazetto' di Frascati. Il casino dei Gomez, Fonseca, Silva, oggi Mergè, opera di Francesco Peparelli”, Palladio 43 (2009), pp. 103-118.

Levin, Michael, J., Agents of Empire. Spanish Ambassadors in Sixteenth-Century Italy. Ithaca, Cornell University Press, 2005.

Machado, Diogo Barbosa, Bibliotheca Lusitana, histórica, critica e cronológica na qual se comprehende a noticia dos authores portugueses e das obras, que compuserão desde o tempo da promulgação da ley da Graça até o tempo prezente. Lisboa, na officina de António Isidoro da Fonseca, 1741-1759, 4 vols.

Mateus, Susana Bastos and Nelson Novoa, James, "A Sixteenth Century Voyage of Legitimacy. The Paths of Jácome and António da Fonseca from Lamego to Rome and Beyond”, Hispania Judaica 9 (2013), pp. 169-192.

Nelson Novoa, James, "Medicine, learning and self representation in seventeenth century Italy. Rodrigo and Gabriel da Fonseca", in António Andrade et alii (orgs.), Humanismo, Diáspora e Ciência (séculos xvi e xviI): estudos, catálogo, exposiçâo. Porto, CMP-BPMP; UA-CLC, 2013, pp. 213-232. 
Nelson Novoa, James, “Unicorns and bezoars in a Portuguese house in Rome: António da Fonseca's Portuguese inventories", Ágora, Estudos Clássicos em Debate 14.1 (2012), pp. 91-112.

Rossholm Lagerlöl, Margaretha, "Life Transformed: Performative Meaning, Analogy, and the Art of Bernini's Funeral Decorations", Konsthistorisk Tidscrift 81 (2012), pp. 2-30. 
A partir dos alvores do século XVI, a matéria médica torna-se indiscutivelmente um tema de primeira grandeza entre os membros da República das Letras, objecto de estudo e de controvérsia entre os mais notáveis humanistas europeus, em particular entre os cultores da arte médica. Entre os autores em destaque neste volume encontram-se, à cabeça, os nomes de Amato Lusitano, Garcia de Orta e Nicolás Monardes, famosos pelos contributos valiosos que deram para o conhecimento do mundo natural. 0 volume encontra-se dividido em duas partes: a primeira, subordinada ao título "Humanismo e Ciência", alberga os estudos que versam sobre todos os autores estudados, à excepção de Amato Lusitano; a segunda está reservada a um conjunto de trabalhos dedicados exclusivamente ao médico albicastrense, cuja autoria se fica a dever, em boa parte, aos membros da equipa do projecto de I\&D "Dioscórides e o Humanismo Português: os Comentários de Amato Lusitano", tomando, por isso, 0 seu próprio título. Nesta segunda parte, oferece-se, desde já, aos leitores uma amostra significativa do trabalho desenvolvido no âmbito do projecto e que culminará, assim se espera, na edição e tradução integral para língua portuguesa das quatro obras previstas de Dioscórides, Amato Lusitano e Pietro Andrea Mattioli. 
